\title{
TRANSPORT OF SOLID PARTICLES WITH FLUID FLOW IN ROTATING PIPES
}

\author{
ZABIROV F.Sh. ${ }^{\text {a }}$, LATYPOV B.M. ${ }^{\text {a }}$, SHARAFIEV R.G. ${ }^{\text {, }}$, GILMANSHIN R.A. ${ }^{\text {b }}$ \\ ${ }^{a}$ Ufa State Petroleum Technological University, Faculty of Mining and Petroleum Engineering, Department of Oil and Gas Field \\ Machinery and Equipment, Russia, e-mail:*zabirov_f@mail.ru \\ ${ }^{\mathrm{b}}$ Ufa State Petroleum Technological University, Faculty of Mechanical Engineering, Department of Oil Processing Equipment \\ Technology, Russia
}

Received: 15.12.2018 / Accepted: 16.02.2019/ Revised: 15.07.2019 / Available online: 10.12.2019

DOI: 10.2478/jaes-2019-0028

KEY WORDS: fluid flow, solid particles, sand, rotating pipe, hollow sucker rods, submersible borehole pump.

\begin{abstract}
:
The article addresses the recent problem of borehole lifting of oil containing sand solids. The presence of sand in oil produced results in a reduced operating life of downhole equipment. The problem of preventing sanding up and sand formation in pumping equipment may be solved and stable sand production may be ensured by producing oil using borehole screw pumps with a surfacetype drive, in which the screw is rotated by rotating hollow rods. Rotating hollow rods improve carry-over of sand particles to the surface with rotational oil flow by imparting additional momentum to these particles. Rotational variables of the pipe (cylinder) that enables transport of solids are set only for the air flow moving in a horizontal pipe (cylinder). The purpose of the study is to establish pipe rotational variables in directional wells that enable stable sand transport with fluid flow. Work results have been obtained from numerical studies using the differential equation system and rules of theoretical solid movement, computer simulation and experimental results processing at a laboratory facility. Theoretical study results have been acknowledged by experimental studies. The work establishes the criteria that allow defining the speed range of directional hollow rods that enables carry-over of solids to the surface with fluid flow. Study results may be used to produce oil with submersible screw pumps with a surface-type drive that use hollow sucker rods for pump down.
\end{abstract}

\section{INTRODUCTION}

In many oil wells, produced fluid contains a lot of solids, which complicates the operation of these wells as it causes increased wear of equipment, jamming of moving parts and sanding up (Bakhtizin, and Smolnikov, 2012; Yakimov, 2014; Latypov et al., 2016; Bakhtizin, Nurgaliev, and Urazakov, 2016). This problem is relevant when producing both high-viscosity oil and water-cut oil (Ibragimov et al., 2003; Urazakov et al., 2003; Morita, and Boyd, 1991; King, Wildt, and O'Connell, 2003). Operation of high-viscosity oil fields with reservoirs represented by poorly cemented sandstones is accompanied by intensive carry-over mechanical impurities to the well due to the high viscosity of fluid flow (Smolnikov, 2015; Matanovic, Cikes, and Moslavac, 2012). When water-cut oil is produced, ingress of solids in the well may also be observed. Due to the low carrying capacity of low-viscosity and water-cut oil (for example, with water volume fraction of 95\%), the volume fraction of solids in the well gradually increases (Mints, and Shubert, 1955; Pirverdyan, 1986). The main methods to protect downhole equipment against solids are the use of mesh filters
(Yakimov, and Kosarev, 2013) and stabilizing formation (Kamaletdinov, and Lazarev, 2010). However, mesh size is subject to such constraining factors as an increase in flow friction that limits well yields and cost efficiency, filter clogging and silting (Smolnikov et al., 2010). This is why ingress of solids in the well may only be limited. In case of substantial ingress of solids in the well, special pumping equipment is used; for example, borehole screw pump plants that are more resistant to increased content of sand solid particles compared to electric submersible centrifugal pumps (ESCP) and borehole oil pumps (BHOP) (Urazakov, Topolnikov, and Abramova, 2011; Nelik, and Brennan, 2005). Borehole oil screw pumps (BHOSP) may be fitted with an electrical submersible motor or surface-type drive; in the latter pumps, rotation of the borehole pump screw is transmitted from the surface-type drive by the sucker rods (Valovskiy, 2012).

When wells are operated using pump units, to prevent sanding up, the fluid flow rate has to be high enough to ensure carryover of solids to the surface. A number of studies have shown that for vertical wells, the ascending fluid velocity has to be

\footnotetext{
* Corresponding author: F.Sh. Zabirov, st. Kosmonavtov, 1, Ufa, Republic of Bashkortostan, 450062, e-mail: zabirov_f@mail.ru
} 
twice as much as the solid settling rate (Adonin, 1964; Sultanov, and Orekeshev, 2005). Some studies of fluid flow rate in inclined pipes have demonstrated that the requisite uprising fluid velocity for these purposes has to be even higher. However, it is not always possible to ensure the requisite uprising fluid velocity in the well. As oil influx rate in unit time depends on geological factors, ascending fluid velocity in oil well tubing may only be increased by decreasing their flow area, which results in higher flow friction.

Orekeshev S. S. (2004) shows results of designing BHOSP with a possibility to pump out fluid by hollow sucker rods. One of the issues that hampered the development of this lift method was the absence of sales of hollow pump rods from the market. Once hollow pump rods by Tenaris (Villasante et al., 2015; Ernst, and Villasante, 2006) were designed, it was possible to continue work in the above directions of research. Latypov B.M. (2012) proposes downhole equipment arrangement that, in addition to dry-up by hollow sucker rods, enables multiple additional process operations, for example, pumping various reagents or hot steam down borehole.

Since most directional oil wells feature significant vertical deviations, the fluid flow rate needed to ensure carry-over of solids, for example, sand, to the surface and to prevent sandingup has to be higher than for a straight hole. This has to be taken into account when choosing pumping equipment. Mellmann J. (2001) determines multiple forms of solid motion in an airfilled rotating cylinder. Mellmann J. (2001) proposes to use Froude number as a ratio of centrifugal and gravity forces that has an effect on solids to determine the form of particle motion in rotating cylinders:

$$
F r=\frac{\omega^{2} \cdot R}{g}
$$

where: $\omega$ is cylinder rate speed, $R$ is cylinder radius, $g$ is free fall acceleration.

However, in a fluid-filled cylinder, apart from centrifugal and gravity forces, particles will also be exposed to the force that occurs when the fluid flow rotates.

\section{MATERIALS AND METHODS}

Theoretical and numerical studies using Matchad software, computer simulation and laboratory experiments on an analytical model of a rotating directional hollow pipe have been conducted in order to determine all the forces that act on a solid when the fluid flow moves in a rotating directional pipe and the motion pattern of these particles with various fluid flow forms and variables of pipe rate speed and lean. Computer simulation has been conducted using ANSYS software system and its application ANSYS ICEM CFD. Laboratory experiments used water with sand of various fractions added in various concentrations.

\section{RESULTS AND DISCUSSIONS}

Forces caused by profile difference of axial and radial fluid flow rates are differently directed, which is why their difference has been ignored to simplify further discussions.
The ad-hoc balance of forces is as follows (Figure 1):

$$
\overrightarrow{F_{R}}=\overrightarrow{F_{g r}}+\overrightarrow{F_{g}}+\overrightarrow{F_{f}}
$$

where: $\overrightarrow{F_{R}}$ is the result of gravity, centrifugal and frictional forces from the rotational fluid flow.

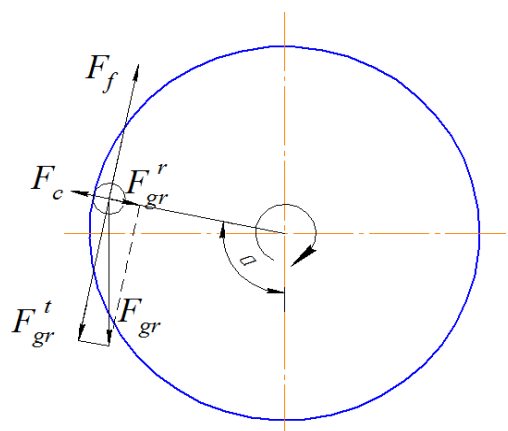

Figure 1. Effects of forces on a solid particle

The force projection balance of equation (2) will be as follows:

$$
\left\{\begin{array}{l}
3 \cdot \pi \cdot \mu \cdot d \cdot v_{r}=\frac{\pi \cdot d}{6} \cdot \Delta \cdot \cdot w^{2} \cdot r+\frac{\pi \cdot d}{6} \cdot \Delta \rho \cdot g \cdot \cos \varphi \\
y \cdot \pi \cdot k \cdot d \cdot v_{t}=3 \cdot \pi \cdot \mu \cdot d \cdot v_{f}-\frac{\pi \cdot d_{3}^{3}}{5} \cdot \Delta \rho \cdot g \cdot \sin \varphi .
\end{array}\right.
$$

After velocities $v_{r}$ and $v_{t}$ have been replaced with time transition derivatives and $\frac{d \varphi}{d t}=\omega$ has been inserted from the lower equation (3) in the upper one, the following has been obtained:

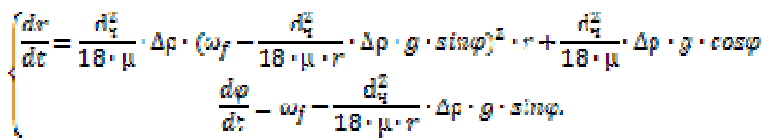

The differential equation system (4) allows us to calculate the solid motion trajectory without regard to Coriolis force. In this case, the initial point of solid breakaway from the pipe wall will be determined based on the following equation:

$$
\left(\omega_{f}-\frac{d_{4}^{2}}{18 \cdot \beta \cdot r} \cdot \Delta \rho \cdot g \cdot \sin \varphi\right)^{2} \cdot r+g \cdot \cos \varphi=0
$$

Solid motion trajectory for a solid particle $0.4 \mathrm{~mm}$ in diameter, quartz sand and water density difference of $1,650 \mathrm{~kg} / \mathrm{m}^{3}$, water dynamic viscosity of $1 \cdot 10^{-3} \mathrm{~Pa} \cdot \mathrm{s}$ rotating in the cylinder of 0.01 $\mathrm{m}$ radius with various rate speeds has been calculated in Matchad based on the differential equation system (4).

Figures 2 and 3 show calculated solid motion trajectories from the point of their breakaway from the pipe to the point of their contact with the pipe wall with various rate speeds of the latter. As these Figures shows, over a certain period, solids moving in a fluid flow do not come into contact with the rotating pipe wall, due to which they are capable of moving axially at a higher rate. 


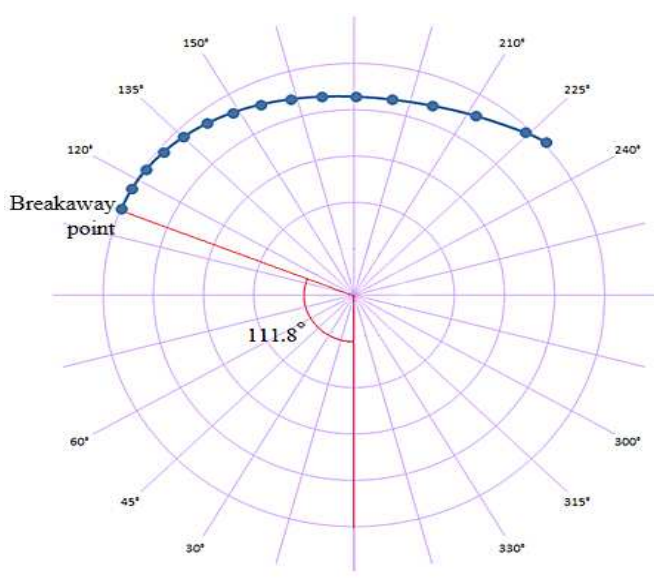

Figure 2. Trajectory of particle motion at cylinder rate speed of $310 \mathrm{rpm}$

Two conditions have to be met to determine the range, with which "cascading" motion may occur:

$$
\begin{aligned}
& F r=\frac{\omega^{2} \cdot r}{g}=\frac{\left(\omega_{f}-\frac{d}{1 E \cdot f \cdot r} \cdot \Delta \rho \cdot g\right)^{2} \cdot r}{g}<1 . \\
& \omega_{f}-\frac{d_{y}^{2}}{16 \cdot H \cdot r} \cdot \Delta \rho \cdot g>0 .
\end{aligned}
$$

If condition (6) is met, a solid particle can deviate from the pipe wall. Based on this condition, the highest pipe rate speed, with which a particle deviates from the wall, may be determined. If condition (7) is met, the lowest pipe rate speed, with which a particle moves in "cascading" motion, is ensured.

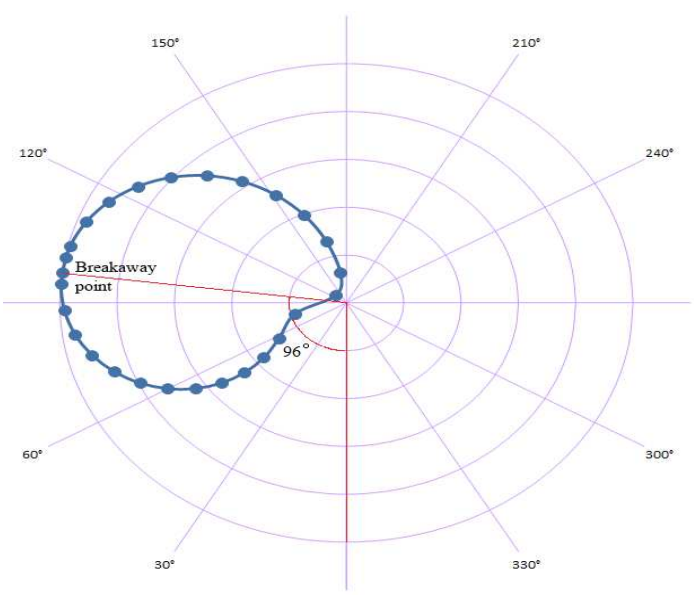

Figure 3. Trajectory of particle motion at cylinder rate speed of $243 \mathrm{rpm}$

The most favourable pipe rate speed for carry-over of sand particles is its value, with which a solid particle is in contact with the wall for as little time as possible.

In the range of highest possible pipe rate speeds, the solid motion trajectory approximates the pipe wall and the time of its contact with the wall increases. In the range of lowest possible pipe rate speeds, the solid motion trajectory is loop-shaped. In this trajectory, the solid moves close to the pipe wall in ascending mode for much of the time.

Solid particles of different sizes present in a rotating pipe may move in different patterns with the same pipe rate speed. This is why to ensure solid carry-over to the surface; the pipe rate speed has to be set so as to enable carry-over of largest solids to the surface since solid size is directly proportional to the fluid flow rate that ensures its carry-over to the surface. Table 1 presents results of numerical calculation of the pipe speed range that enables "cascading" trajectory of solid motion in fluid flow.

Table 1. Pipe speed range, at which the cascading motion of solid particles can be observed

\begin{tabular}{|c|c|c|c|c|c|}
\hline $\begin{array}{c}\text { Difference } \\
\text { between fluid } \\
\text { and solid } \\
\text { particle } \\
\text { densities, } \\
\mathrm{kg} / \mathrm{m}^{3}\end{array}$ \\
\hline $\begin{array}{c}\text { Cylinder } \\
\text { diameter, mm }\end{array}$ & \multicolumn{5}{|c|}{1,650} \\
\hline $\begin{array}{c}\text { Fluid } \\
\text { viscosity, Pa.s }\end{array}$ & \multicolumn{5}{|c|}{20} \\
\hline $\begin{array}{c}\text { Particle } \\
\text { diameter, mm }\end{array}$ & 0.1 & 0.2 & 0.3 & 0.4 & 0.5 \\
\hline $\begin{array}{c}\text { Maximum } \\
\text { pipe rate } \\
\text { speed, rpm }\end{array}$ & 298 & 303 & 315 & 350 & 404 \\
\hline $\begin{array}{c}\text { Minimum pipe } \\
\text { rate speed, } \\
\text { rpm }\end{array}$ & 9 & 34 & 78 & 137 & 215 \\
\hline $\begin{array}{c}\text { Settling rate of } \\
\text { solid particles, } \\
\text { m/s }\end{array}$ & 0.00067 & 0.00263 & 0.00577 & 0.00992 & 0.01490 \\
\hline
\end{tabular}

Three conditions have to be met to calculate the speed range of the pipe at an angle ${ }^{\alpha}$ to the horizontal, with which carry-over of solids to the surface is enabled:

$$
\left\{\begin{array}{c}
F r=\frac{\omega^{2} \cdot r^{r}}{g \cdot \cos \alpha}=\frac{\left(\omega_{f}-\frac{d_{\mathrm{q}}^{2}}{18 \cdot \mu \cdot r} \cdot \Delta p \cdot g \cdot \sin \alpha\right)^{2} \cdot r}{g}<1 \\
\omega_{f}-\frac{d_{\mathrm{q}}^{2}}{18 \cdot \mu \cdot r} \cdot \Delta \rho \cdot g \cdot \cos \alpha>0 \\
v_{o c}>\frac{d_{\mathrm{u}}^{2}}{18 \cdot \mu} \cdot \Delta p \cdot g \cdot \sin \alpha .
\end{array}\right.
$$

Table 2 presents numerical results of calculation of the speed range of the fluid-filled pipe $20 \mathrm{~mm}$ in diameter at various angles to the horizontal that meet conditions (8).

In order to verify the validity of the results of numerical studies aimed to calculate the pipe speed ranges that ensure surfacing of solids in a fluid flow, a rotating pipe model has been built and subjected to computer simulation using ANSYS software system. The model of a pipe $20 \mathrm{~mm}$ in diameter and $400 \mathrm{~mm}$ long has been used to simulate the process of solid carry-over with fluid flow in a rotating pipe. ANSYS ICEM CFD 
application has been used to build a finite element grid comprising 132,079 points and 125,692 elements.

Table 2. Pipe speed ranges, with which the cataracting motion of solid particles in fluid may be observed

\begin{tabular}{|l|c|c|c|c|c|}
\hline $\begin{array}{l}\text { Difference of fluid } \\
\text { and particle } \\
\text { densities, } \mathrm{kg} / \mathrm{m}^{3}\end{array}$ & \multicolumn{5}{|c|}{$0.5,650$} \\
\hline $\begin{array}{l}\text { Particle diameter, } \\
\text { mm }\end{array}$ & \multicolumn{5}{|c|}{20} \\
\hline Pipe diameter, mm & \multicolumn{5}{|c|}{0.51} \\
\hline Fluid viscosity, Pa·s & \multicolumn{5}{|c|}{} \\
\hline $\begin{array}{l}\text { Angle of inclination, } \\
\text { degrees }\end{array}$ & 0 & 30 & 45 & 60 & 75 \\
\hline $\begin{array}{l}\text { Maximum pipe rate } \\
\text { speed, rpm }\end{array}$ & 298 & 386 & 403 & 398 & 360 \\
\hline $\begin{array}{l}\text { Minimum pipe rate } \\
\text { speed, rpm }\end{array}$ & 215 & 186 & 152 & 107 & 56 \\
\hline $\begin{array}{l}\text { Minimum required } \\
\text { axial speed, m/s }\end{array}$ & $>0$ & 0.113 & 0.159 & 0.195 & 0.217 \\
\hline
\end{tabular}

The following data have been used as computer simulation initial data. Water with a density of $997 \mathrm{~kg} / \mathrm{m}^{3}$ and viscosity of $0.001 \mathrm{~Pa} \cdot \mathrm{s}$ has been chosen as a fluid. Diameter range of solids (sand) transported with fluid: $0.1 ; 0.2 ; 0.3 ; 0.4$ and $0.5 \mathrm{~mm}$. Solid (quartz sand) density is $2,650 \mathrm{~kg} / \mathrm{m}^{3}$. Schiller Neuman model has been used to calculate coefficient $\mathrm{C}_{\mathrm{d}}$ that describes the particle flowing process. The rate of solid and fluid input flow has been assumed equal to $0.08 \mathrm{~m} / \mathrm{s}$ and its vector is directed along the pipe's long axis. The flow rate of solids of each diameter has been set at 0.5 grams per second. The pipe has been rotated about its long axis at a set rate speed.

Results of computer simulation shows that solid particles have different motion trajectories. Larger particles follow a more curved trajectory closer to the centre of the cylinder. Besides, larger particles have longer contact with the wall, which is why their average axial velocity has to be higher compared to smaller particles.

Table 3 shows values of average axial (along axis Y) velocity of solid particles obtained as a result of computer simulation.

According to table 1, when the pipe rate speed is $300 \mathrm{rpm}$, cascading motion is possible for particles with a size of 0.3 to $0.5 \mathrm{~mm}$, which matches the results of computer simulation using ANSYS software system shown in table 3. Computer simulation results also showed that solid particles $0.2 \mathrm{~mm}$ in diameter will move along the pipe wall as Froude number for this size comes close to one.

In order to experimentally verify the validity of the results of theoretical studies and computer simulation of the nature of the influence of the pipe rate speed on the sand carry-over process, the laboratory facility shown in Figure 4 has been designed. In this facility, the model of a pipe $2 \mathrm{~m}$ long with an inside diameter of $20 \mathrm{~mm}$ has been made of a transparent material to enable visual monitoring of the solid (sand) motion trajectory. The pipe model is secured on a beam that may be inclined from 0 to 90 degrees.
The beam angle of inclination is defined by trigonometric formulas based on the leg length ratio of the beam. Water has been supplied to the pipe model from the laboratory's internal water supply system. The pipe model has been rotated with an electric drive of $1,050 \mathrm{~W}$ with a rate speed adjustable from 0 to $550 \mathrm{rpm}$. The fluid flow rate has been determined volumetrically using a metering tank and a stopwatch.

Table 3. Average values of the axial velocity of solid particles

\begin{tabular}{|l|c|c|c|}
\hline Particle size, $\mathrm{mm}$ & 0.1 & 0.2 & 0.3 \\
\hline Average axial velocity, m/s & 0.051 & 0.053 & 0.06 \\
\hline $\begin{array}{l}\text { Froude number calculated } \\
\text { from equation (6) }\end{array}$ & 0.950 & 0.789 & 0.555 \\
\hline Particle size, mm & 0.4 & 0.5 & - \\
\hline Average axial velocity, m/s & 0.067 & 0.072 & - \\
\hline $\begin{array}{l}\text { Froude number calculated } \\
\text { from equation (6) }\end{array}$ & 0.295 & 0.081 & \\
\hline
\end{tabular}

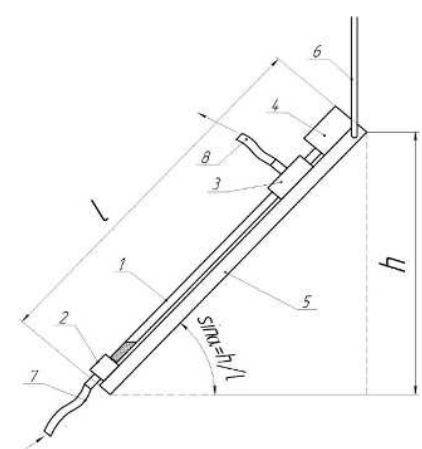

Figure 4. Diagram of a laboratory facility

(1-transparent pipe, 2 and 3 -swivels, 4 -electric drive, 5 -beam, 6 -rope, 7 -supply pipe, 8 -outlet pipe)

Sand added in water has been pre-screened using a sieve with a mesh size of $(0.5 \times 0.5) \mathrm{mm}$.

Laboratory experiments were conducted in the following sequence. First, quartz sand was filled in the pipe model in the amount so that its volume fraction in the body cavity of the pipe model was $5 \%$.

Next, required angle of inclination of the beam was set. Next, water was supplied to the pipe model through a feeding hose and a control cock so that all sand particles were removed with the minimum water flow rate.

Laboratory studies have been conducted in line with the program of a multilevel two-factor experiment to assess the effect of rate speed and angle of inclination of the pipe model on the fluid velocity rate required to remove sand particles from the pipe.

Combined charts of corresponding approximating curves shown in Figure 5 and 6 have been plotted based on the results of experimental data statistical processing.

Figure 5 shows a combined chart of approximating curves of the effect of the angle of inclination on the water velocity rate that ensures sand removal at various rate speeds of the pipe model. With rate speeds of 0 to 219 , a decrease in fluid flow velocity required to ensure sand removal is observed. 
In the range of 219 to $308 \mathrm{rpm}$, there is a minor change in this critical value of fluid flow velocity, after which it grows with an increase in rate speed of the pipe model.

When fluid flows in the rotating pipe model, the critical speed, at which all the sand particles are removed by ascending fluid from the pipe model has the highest value with the angles of inclination of 50-60 degrees and the lowest - with the zero angle of inclination of the pipe model.

For an actual well with a deviated hole, the fluid flow rate required to remove sand throughout the length of the borehole has to be higher than the maximum value of the critical speed required ensuring sand removal in one of all available borehole sections with different angles of inclination.

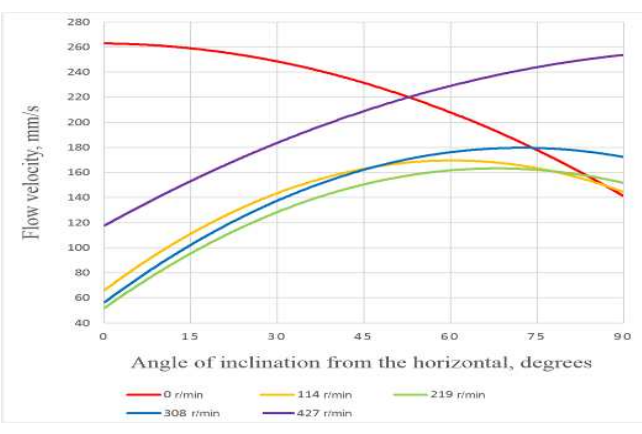

Figure 5. Combined chart of approximating curves of the effect of the angle of inclination on the velocity required for sand removal at various rate speeds

Figure 6 shows a combined chart of approximating curves of the effect of the angle of inclination on the pipe model on the speed that ensures the required rate of sand removal at various rate speeds of the pipe.

Benchmarking of the results of the theoretical studies that have established numerical values of the pipe speed range that enable the lowest values of fluid flow rate for sand removal (table 2) with experimental data has ascertained that the valley point of regression curves (Figure 6) is close to the centre of the theoretical speed range.

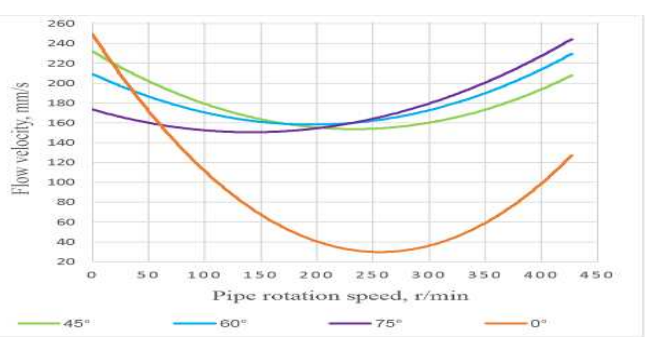

Figure 6. Combined chart of approximating curves of the effect of the angle of inclination on the speed required for sand removal at various rate speeds

Table 4 shows results of benchmarking of the medium value of the pipe speed range for the cascading form of sandy fluid motion determined based on theoretical study results with the valley points of regression curves determined during experimental studies.
Table 4. Results of calculating the pipe rate speed providing the minimum speed required for sand removal

\begin{tabular}{|c|c|c|c|c|}
\hline $\begin{array}{l}\text { Difference of fluid and } \\
\text { particle densities, } \\
\mathrm{kg} / \mathrm{m}^{3}\end{array}$ & \multicolumn{4}{|c|}{1,650} \\
\hline Particle diameter, $\mathrm{mm}$ & \multicolumn{4}{|c|}{0.5} \\
\hline $\begin{array}{l}\text { Pipe inside diameter, } \\
\text { mm }\end{array}$ & \multicolumn{4}{|c|}{20} \\
\hline Fluid viscosity, $\mathrm{Pa} \cdot \mathrm{s}$ & \multicolumn{4}{|c|}{0.001} \\
\hline $\begin{array}{l}\text { Angle of inclination, } \\
\text { degrees }\end{array}$ & 0 & 45 & 60 & 75 \\
\hline $\begin{array}{l}\text { Maximum pipe rate } \\
\text { speed, rpm }\end{array}$ & 298 & 403 & 398 & 360 \\
\hline $\begin{array}{l}\text { Minimum pipe rate } \\
\text { speed, rpm }\end{array}$ & 215 & 152 & 107 & 56 \\
\hline $\begin{array}{l}\text { Medium pipe speed } \\
\text { range, rpm }\end{array}$ & 256.5 & 277.5 & 252.5 & 208 \\
\hline $\begin{array}{l}\text { Valley points of } \\
\text { regression curves, rpm }\end{array}$ & 280.3 & 233.9 & 225.8 & 203.6 \\
\hline $\begin{array}{l}\text { Divergence of } \\
\text { frequency values, \% }\end{array}$ & 9 & 16 & 11 & 2 \\
\hline $\begin{array}{l}\text { Fluid flow rate } \\
\text { calculated from the } \\
\text { regression equation } \\
\text { with the medium value } \\
\text { of the speed range, } \\
\mathrm{mm} / \mathrm{s}\end{array}$ & 56 & 139 & 155 & 151 \\
\hline $\begin{array}{l}\text { Fluid flow rate } \\
\text { calculated from the } \\
\text { regression equation at } \\
\text { the minimum point, } \\
\mathrm{mm} / \mathrm{s}\end{array}$ & 56 & 142 & 154 & 151 \\
\hline $\begin{array}{l}\text { Divergence of values } \\
\text { of fluid flow rates, } \%\end{array}$ & 0 & 2.3 & 0.5 & 0 \\
\hline
\end{tabular}

\section{CONCLUSIONS}

1. A criterion has been determined that allows us to calculate the speed range of hollow sucker rods, with which uprising fluid velocity required for carry-over of sand particles from the well to the surface is minimum.

2. When the fields complicated with sand ingress and characterized by low yields are operated, it is recommended to use directional wells fitted with borehole screw pump units with pumping out production fluid by hollow rotating sucker rods.

\section{References:}

Adonin, A.N. 1964. Processy glubinno-nasosnoj neftedobychi (RU) (Bottom-hole oil production processes). Nedra, Moscow.

Bakhtizin, R.N., Nurgaliev, R.Z., and Urazakov, K.R. 2016. Ekspluatacija nasosnyh skvazhin, oslozhnennyh mehanicheskimi primesjami (RU) (Operation of pumping wells complicated with mechanical impurities). UGNTU publishing house, Ufa.

Bakhtizin, R.N., and Smolnikov, S.V. 2012. Osobennosti dobychi nefti s vysokim soderzhaniem mehanicheskih primesej (RU) (Features of oil production with high content of 
mechanical impurities). Electronic scientific journal Neftegazovoye delo, 5, pp. 159-169, http://www.ogbus.ru/authors/Bakhtizin/Bakhtizin_4.pdf.24, (view at 01 January 2017).

Ernst H. A., and Villasante J. A. 2006. Hollow sucker rod connection with second torque shoulder. Patent US 7431347B2, E21B17/042, US, NY.

Ibragimov, N.G., Khafizov, A.R., Shaydakov, V.V., Khaydarov, F.R., Yemelyanov, A.V., Golubev M.V., Kashtanova L.E., Chernova K.V., Bugai D.E., and Laptev A.B. 2003. Oslozhnenija $v$ neftedobyche (RU) (Complications of oil production). Monographiya publishing house, Ufa.

Kamaletdinov, R.S., and Lazarev, A.B. 2010. Obzor sushhestvujushhih metodov bor'by $\mathrm{s}$ mehprimesjami (RU) (Review of current methods of protection from mechanical impurities). Inzhenernaya praktika, 2, pp. 6-13.

King, G.E, Wildt, P.J., and O'Connell, E. 2003. Sand Control Completion Reliability and Failure Rate Comparison with a Multi-Thousand Well Database. SPE Annual Technical Conference and Exhibition, https://doi.org/10.2118/84262-MS, (view at 06 June 2012).

Latypov, B.M. Topolnikov A.S., Komkov A.G., and Ismagilov R.R. 2016. Vlijanie uslovij jekspluatacii na narabotku shtangovyh vintovyh nasosnyh ustanovok (RU) (Impact of operation conditions on the pump down time of progressive sucker rod pumping units). Neftegazovoye delo, 14(2), pp. 5560, https://elibrary.ru/item.asp?id=27216409, (view at 01 January 2017).

Latypov, B.M. 2012. Ustanovka shtangovogo vintovogo nasosa dlja dobychi nefti v oslozhnennyh uslovijah (RU) (Progressing cavity pump for oil production under complicated conditions). Neftegazovoye delo, 10(1), pp. 13-15.

Matanovic, D., Cikes, M., and Moslavac, B. 2012. Sand Control in Well Construction and Operation. Springer-Verlag Berlin Heidelberg, Berlin.

Mellmann, J. 2001. The transverse motion of solids in rotating cylinders-forms of motion and transition behavior. Powder Technol, 118, pp. 251-270.

Mints, D.M., and Shubert, S.A. 1955. Gidravlika zernistyh materialov (RU) (Hydraulics of granular material). Publishing house of the Ministry of Utilities of the RSFSR, Moscow.

Morita, N., and Boyd, P.A. 1991. Typical Sand Production Problems: Case Studies and Strategies for Sand Control. SPE 22739, Society of Petroleum Engineers, Inc., pp. 801-812.

Nelik, L., and Brennan, J.R. 2005. Gulf Pump Guides: Progressing Cavity Pumps, Downhole Pumps, and Mud motors. Gulf Publishing Company, Houston.

Orekeshev, S.S. 2004. Sovershenstvovanie tehnicheskih sredstv dlja dobychi nefti vintovymi nasosnymi ustanovkami pri projavlenijah peska $i$ gaza (RU) (Improvement of technical means of oil production using screw pumps in the presence of oil and gas). Ph.D. Diss in Engineering. Ufa State Petroleum Technical University, Ufa.

Pirverdyan, A.M. 1986. Zashhita skvazhinnogo nasosa ot gaza $i$ peska (RU) (Protection of downhole pump from gas and sand). Nedra, Moscow.

Smolnikov, S.V. 2015. Povyshenie jeffektivnosti jekspluatacii produktivnyh plastov, slozhennyh slabocementirovannymi peschanikami (RU) (Increase of the operation efficiency of productive formations composed of poorly cemented sands). $\mathrm{Ph} . \mathrm{D}$. Diss in Engineering, A.A. Blagonravov Institute of Engineering Science of the Russian Academy, Moscow.

Smolnikov, S.V., Urazakov, K.R., Bakhtizin, R.N., and Topolnikov, A.S. 2010. Metody zashhity nasosnogo oborudovanija dlja dobychi nefti ot mehanicheskih primesej (RU) (Methods of protection of oil-producing pumps from mechanical impurities). Neftegazovoye delo, Ufa.

Sultanov, B.Z., and Orekeshev, S.S. 2005. Voprosy vynosa peska $\mathrm{v}$ processe jekspluatacii neftjanyh skvazhin (RU) (Sand production in the process of oil wells operation). Neftegazovoye delo, 1, pp. 10.

Urazakov, K.R., Topolnikov, A.S., and Abramova, E.V. 2011. Oblast' jeffektivnogo primenenija vintovyh nasosov dlja dobychi nefti (RU) (Areas of efficient application of screw pumps for oil production). Territoriya Neftegaz, 2, pp. 16-21.

Urazakov, K.R., Bogomolnyy, Ye.I., Seytpagambetov, Zh.S., and Gazarov, A.G. 2003. Nasosnaja dobycha vysokovjazkoj nefti iz naklonnyh i obvodnennyh skvazhin (RU) (Production of high-viscosity oil from inclined and water wells). In M.D. Valeev (Ed.) Nedra-Biznestsentr, Moscow, p. 303.

Valovskiy, V.M. 2012. Vintovye nasosy dlja dobychi nefti: uchebnoe posobie (RU) (Screw pumps for oil production). Neftyanoye khozyaystvo publishing house, Moscow.

Villasante, J. A., Mantovano, L. O., Ernst, H. A., and Pereyra, M. G. 2015. Development of a new hollow sucker rod family for rotating pumping (progressive cavity pump systems). Journal of Petroleum Science and Engineering, 134(October), pp. 277-289.

Yakimov, S.B. 2014. Separatory peska dlja zashhity pogruzhnyh nasosov. Tekushhaja situacija i perspektivy primenenija tehnologii (RU) (Sand separation units to protect submersible pumps. Current situation and prospects for the technology application). Territoriya neftegaz, 2, pp. 44-58.

Yakimov, S.B., and Kosarev, I.A. 2013. Izuchenie jeffektivnosti primenenija setchatyh fil'trov dlja zashhity JECN pri bol'shom vynose proppanta (RU) (Study of the effectiveness of screen filters to protect ESP from large proppant flowback). Oil and gas industry equipment and technologies: Scientific and technical journal VNIIOENG-Moscow, 6, pp. 29-32. 